\title{
ANALYSIS OF HPCC PAVEMENTS USING KENPAVE FEA SOFTWARE
}

\author{
Bharath Babu M.D ${ }^{1}$, Amarnath M.S ${ }^{2}$, Suresh Kumar K.S ${ }^{3}$ \\ ${ }^{1}$ Post-graduation Engineering Trainee, M/S L\&T Construction, Chennai, babucivil013@gmail.com \\ ${ }^{2}$ Professor in Highway Engineering, Bangalore University, Bangalore: amaranth_ms@rediffmail.com \\ ${ }^{3}$ Research scholar, Department of Civil Engineering, Bangalore University, Bangalore: sknitt@gmail.com
}

\begin{abstract}
A comprehensive research work on High Performance Cement Concrete (HPCC) pavements is being conducted at Bangalore University. As a part of the study static flexural strengths are determined for Conventional Concrete (CC), Silica Fume Concrete (SFC), High Volume Fly Ash Concrete (HVFAC), Fiber Reinforced Concrete (FRC), and Fiber Reinforced High Volume Fly Ash Concrete (FRHVFAC) using third point loading in the laboratory. Laboratory fatigue teats were also carried out on HPCC beam specimens and number of repetitions to failure determined. Using the results fatigue models and stress charts were developed and slab thicknesses of the HPCCs designed. In this paper an attempt is made to analyze the HPCC pavements using a 2-D Finite Element Analysis (FEA) software - KENPAVE. The critical flexural stresses obtained using the FEA software are compared with stresses obtained from the experimental study. The design life of the HPCC pavements is also analyzed using the FEA software. The variation in flexural stresses as obtained from FEA software when compared with actual flexural stresses ranges from 5 to $6 \%$. Damage analysis using FEA software shows that predicted design life obtained ranges from 1 to $12 \%$ for various HPCCs. The $12 \%$ variation is for Fiber Reinforced HPCCs indicating that the design life of fiber reinforced HPCCs are more.
\end{abstract}

Keywords: high performance concrete, flexural stresses, finite element analysis software, damage analysis.

\section{INTRODUCTION}

ACI defines HPC as "Concrete meeting special combinations of performance and uniformity requirements that cannot always be achieved routinely using conventional constituents and normal mixing, placing and curing practices". Important governing factors for HPCs are strength, long term durability, serviceability as determined by crack and deflection control, as well as response to long term environmental effects.

A number of Finite Element Analysis (FEA) software is available for analyzing rigid pavements. These software's analyze pavements based on the finite-element method, in which the slab is divided into rectangular finite elements. KENPAVE is a 2D - FEA software developed by Huang ${ }^{(10)}$ used in this study. To analyze rigid pavements using KENPAVE FEA software the inputs required are slab geometry, material properties and wheel load. The stresses and deflections of the slab, design life and cracking index are obtained as the outputs.

\section{MIX PROPORTIONS AND STRENGTH PROPERTIES OF C CS AND HPCCS}

Experimental studies were conducted by Kamalakar [1] on various HPCCs at Bangalore University. The designed mix proportions and strength properties of Conventional Concrete (CC), Silica Fume Concrete (SFC), High Volume Fly Ash Concrete (HVFAC), Fiber Reinforced Concrete (FRC), and Fiber Reinforced High Volume Fly Ash Concrete (FR HVFAC) obtained from the studies on the HPCC mixes are shown in Tables $1,2 \& 3$.

Table 1 Proportions of different HPCC mixes

\begin{tabular}{|l|c|c|c|c|c|}
\hline \multicolumn{1}{|c|}{ Mix } & M1 & M2 & M3 & M4 & M5 \\
\hline Water / binder ratio & 0.39 & 0.39 & 0.39 & 0.39 & 0.46 \\
\hline $\begin{array}{l}\text { Super-plasticizer, \% Rheobuild- } \\
816^{*} \\
\text { Conplast ms 432** }\end{array}$ & 0 & $0.5^{*}$ & $1.25^{*}$ & $1.5^{*}$ & $0.3^{* *}$ \\
\hline Cement, $\mathrm{kg} / \mathrm{m}^{3}$ & 405 & 417 & 208.5 & 208.5 & 372.6 \\
\hline Fly ash $/$ silica fume, $\mathrm{kg} / \mathrm{m}^{3}$ & 0 & 0 & 208.5 & 208.5 & 32.4 \\
\hline
\end{tabular}




\begin{tabular}{|l|c|c|c|c|c|}
\hline Steel fibers, \% & 0 & 1.25 & 0 & 1.25 & 0 \\
\hline Fine aggregate, $\mathrm{kg} / \mathrm{m}^{3}$ & 750 & 565.00 & 565.02 & 565.02 & 814.35 \\
\hline $\begin{array}{l}\text { Coarse aggregate fraction -I, } \\
\mathrm{kg} / \mathrm{m}^{3}\end{array}$ & 720 & 786.00 & 786.00 & 786.00 & 676.36 \\
\hline $\begin{array}{l}\text { Coarse aggregate } \\
\text { fraction -II kg/m3 }\end{array}$ & 355 & 387.00 & 387.00 & 387.00 & 332.64 \\
\hline Water, $\mathrm{kg} / \mathrm{m}^{3}$ & 150 & 162.53 & 162.53 & 162.53 & 170.2 \\
\hline Slump, $\mathrm{mm}$ & 13 & 14 & 15 & 14 & 20 \\
\hline Density of concrete, $\mathrm{Kg} / \mathrm{m}^{3}$ & 2500 & 2540 & 2350 & 2400 & 2550 \\
\hline
\end{tabular}

Where,

M1- Conventional M30 grade Concrete (CC)

M2- Fiber reinforced Conventional M40 grade Concrete (FRC)

M3- High volume fly ash concrete (50\% replacement of cement with fly ash) (HVFAC)
M4- Fiber reinforced High volume fly ash concrete (FRHVFAC)

M5- Silica fume concrete ( $8 \%$ replacement of cement by silica fume) (SFC)

Table 2 Compressive Strength Test Results of Concrete Mixes

\begin{tabular}{|c|c|c|c|c|c|c|}
\hline Sl. No. & $\begin{array}{c}\text { Number of days of } \\
\text { curing }\end{array}$ & $\begin{array}{l}\text { M1, } \\
\text { MPa }\end{array}$ & $\begin{array}{c}\text { M2, } \\
\text { MPa }\end{array}$ & $\begin{array}{c}\text { M3, } \\
\text { MPa }\end{array}$ & $\begin{array}{c}\text { M4, } \\
\text { MPa }\end{array}$ & $\begin{array}{c}\text { M5, } \\
\text { MPa }\end{array}$ \\
\hline 1 & 3 & 21.99 & 24.52 & 17.98 & 19.62 & 33.77 \\
\hline 2 & 7 & 34.22 & 37.88 & 22.15 & 24.46 & 42.07 \\
\hline 3 & 28 & 48.23 & 51.42 & 30.55 & 33.12 & 49.48 \\
\hline 4 & 56 & - & - & 48.82 & 51.94 & - \\
\hline
\end{tabular}

Table 3 Static Flexural Strength Test Results of Concrete Mixes

\begin{tabular}{|c|c|c|c|c|c|c|c|c|c|c|c|}
\hline \multirow{2}{*}{$\begin{array}{l}\text { Sl. } \\
\text { No. }\end{array}$} & \multirow{2}{*}{$\begin{array}{l}\text { No. of } \\
\text { days }\end{array}$} & \multicolumn{2}{|c|}{ M1 } & \multicolumn{2}{|c|}{ M2 } & \multicolumn{2}{|c|}{ M3 } & \multicolumn{2}{|c|}{ M4 } & \multicolumn{2}{|c|}{ M5 } \\
\hline & & $\begin{array}{c}\text { Load } \\
\mathbf{k N}\end{array}$ & $\begin{array}{c}\mathbf{f}_{\mathrm{cr}} \\
\mathbf{M P a}\end{array}$ & $\begin{array}{c}\text { Load } \\
\mathbf{k N}\end{array}$ & $\mathbf{f}_{\mathrm{cr}} \mathbf{M P a}$ & $\begin{array}{c}\text { Load } \\
\text { kN }\end{array}$ & $\mathbf{f}_{\mathrm{cr}} \mathrm{MPa}$ & $\begin{array}{c}\text { Load } \\
\mathbf{k N}\end{array}$ & $\begin{array}{c}\mathbf{f}_{\mathrm{cr}} \\
\mathbf{M P a}\end{array}$ & $\begin{array}{c}\text { Load } \\
\mathbf{k N}\end{array}$ & $\begin{array}{c}\mathbf{f}_{\mathrm{cr}} \\
\mathbf{M P a}\end{array}$ \\
\hline 1 & 28 & 11.92 & 4.76 & 12.7 & 5.08 & 8.12 & 3.33 & 9.86 & 3.94 & 15.75 & 5.75 \\
\hline 2 & 56 & - & - & - & - & 12.32 & 4.93 & 13.06 & 5.22 & - & - \\
\hline
\end{tabular}

$\mathrm{f}_{\mathrm{cr}}$ is the static flexural strength

\section{DETERMINATION OF FLEXURAL STRESSES}

Flexural stresses in CC and HPCC mixes, M1 to M5 for single axle loads ranging from 10 to 20 tons and tandem axle loads ranging from 16 to 36 tons for varying k-values and slab thicknesses are evaluated using IRC: 58:2002 [2]. Typical flexural stresses obtained under 36 ton tandem axle load and subgrade soil with $\mathrm{k}=10 \mathrm{MPa} / \mathrm{m}$ are shown in Table 4 . 
Table 4 Flexural Stresses (MPa) as per IRC:58-2002

\begin{tabular}{|l|c|c|c|c|c|c|c|c|c|c|c|c|c|}
\hline Thickness $\mathbf{~ m m}$ & $\mathbf{1 4 0}$ & $\mathbf{1 6 0}$ & $\mathbf{1 8 0}$ & $\mathbf{2 0 0}$ & $\mathbf{2 2 0}$ & $\mathbf{2 4 0}$ & $\mathbf{2 6 0}$ & $\mathbf{2 8 0}$ & $\mathbf{3 0 0}$ & $\mathbf{3 2 0}$ & $\mathbf{3 4 0}$ \\
\hline \multicolumn{10}{|c|}{$\mathbf{1 0} \mathbf{M P a} / \mathbf{m}$ and 36 ton tandem axle load } \\
\hline M1 & 6.33 & 5.24 & 4.41 & 3.76 & 3.25 & 2.83 & 2.49 & 2.21 & 1.97 & 1.77 & 1.60 \\
\hline M2 & 6.37 & 5.27 & 4.43 & 3.78 & 3.26 & 2.84 & 2.50 & 2.22 & 1.98 & 1.78 & 1.60 \\
\hline M3 & 6.47 & 5.34 & 4.49 & 3.83 & 3.30 & 2.88 & 2.53 & 2.24 & 2.00 & 1.79 & 1.62 \\
\hline M4 & 6.50 & 5.37 & 4.51 & 3.84 & 3.31 & 2.89 & 2.54 & 2.25 & 2.01 & 1.80 & 1.62 \\
\hline M5 & 6.56 & 5.41 & 4.54 & 3.87 & 3.34 & 2.91 & 2.56 & 2.27 & 2.02 & 1.81 & 1.63 \\
\hline
\end{tabular}

\section{COMPARISION OF FLEXURAL STRESSES}

Flexural stresses obtained using IRC equation under 20 ton single axle load for $200 \mathrm{~mm}$ thick slab on sub grade soil with various k-values are compared with stresses obtained using FEA software. The comparisons are shown in Table 5.

Table 5 Stress Comparisons between IRC and FEA Software

\begin{tabular}{|c|c|c|}
\hline $\begin{array}{c}\text { Modulus of Sub grade reaction } \\
(\mathrm{MPa} / \mathrm{m})\end{array}$ & KENPAVE (MPa) & IRC:58-2002 (MPa) \\
\hline $\mathrm{k}=60$ & 3.85 & 3.63 \\
\hline $\mathrm{k}=80$ & 3.61 & 3.45 \\
\hline $\mathrm{k}=100$ & 3.44 & 3.32 \\
\hline $\mathrm{k}=150$ & 3.33 & 3.07 \\
\hline $\mathrm{k}=300$ & 2.87 & 2.65 \\
\hline
\end{tabular}

It is observed that the flexural stresses determined using FEA software are 5 to $6 \%$ more than flexural stresses determined by IRC equation.
IRC: 58:2002.The parameters considered for the design and the thicknesses arrived at are shown in Table 6. All the slabs are designed for a 20 year design period.

\section{DAMAGE ANALYSIS OF DESIGNED HPCC}

\section{SLABS USING KENPAVE FEA SOFTWARE}

The design thicknesses of the HPCC slabs considered in this study are arrived at for the axle load spectrum suggested in

Table 6 Parameters for design thickness

\begin{tabular}{|c|c|c|c|c|}
\hline Type of Concrete & E, MPa & $\mathbf{f}_{\text {ck }}, \mathbf{M P a}$ & $\mathbf{f}_{\text {cr, }}, \mathbf{M P a}$ & Thickness, mm \\
\hline M1 & 31000 & 48 & 4.92 & 280 \\
\hline M2 & 32000 & 51 & 5.14 & 270 \\
\hline M3 & 35000 & 49 & 4.88 & 270 \\
\hline M4 & 36000 & 52 & 5.19 & 260 \\
\hline
\end{tabular}


Where: $\mathrm{E}$ is the modulus of elasticity, fck is the characteristic compressive strength and for is the static flexural strength.

Damage analysis is conducted by using KENPAVE FEA software for the HPCC slabs designed. The same parameters considered in Table 6 and loads as per IRC axle load spectrum are considered as the input parameters in the FEA software.
The design life and cracking index are determined by running the software. The results obtained are shown in Table 7. It is observed that the design life obtained is almost equal to the design period of 20 years except for fiber reinforced pavements. The design lives of fiber reinforced pavements are found to be 10 to $12 \%$ higher than the conventional concrete pavements

Table 7 Cracking Index and Design Life using FEA Software

\begin{tabular}{|c|c|c|c|c|c|c|}
\hline Type of Concrete & $\begin{array}{c}\text { Thickness, } \\
\mathbf{m m}\end{array}$ & $\mathbf{E , ~ M P a}$ & $\mathbf{f}_{\text {ck, }}$ MPa & $\mathbf{f}_{\text {cr, }}$ MPa & $\begin{array}{c}\text { Cracking } \\
\text { Index }\end{array}$ & $\begin{array}{c}\text { Design life, } \\
\text { Years }\end{array}$ \\
\hline M1 & 280 & 31000 & 48 & 4.92 & 0.050 & 19.74 \\
\hline M2 & 270 & 32000 & 51 & 5.14 & 0.042 & 23.46 \\
\hline M3 & 270 & 35000 & 49 & 4.88 & 0.052 & 18.98 \\
\hline M4 & 260 & 36000 & 52 & 5.19 & 0.039 & 25.26 \\
\hline
\end{tabular}

\section{CONCLUSIONS}

The following conclusions are drawn by analyzing the HPCC pavements using KENPAVE FEA software:

- The flexural stresses determined using FEA software for the HPCCs analyzed are 5 to $6 \%$ more than flexural stresses determined by IRC equation.

- The design life obtained by conducting damage analysis using KENPAVE FEA software is almost the same as the design period considered for $\mathrm{CC}$ and HPCC pavements without fibre reinforcement.

- The design life obtained for fiber reinforced HPC's slabs are more by 10 to $12 \%$ than the design period considered.

\section{REFERENCES}

[1] Kamalakar "Development of probabilistic Failure models for the design of HPCC Pavements", M.E. Thesis (un published), submitted to Department of Civil Engineering, Bangalore University, Bangalore, India, (December 2012).

[2] IRC: 58 - 2002, "Guidelines for the Design of Plain Jointed Rigid Pavements for Highways", The Indian Road Congress, Jamnagar House, New Delhi.

[3] Suresh Kumar. K.S. and Amaranth. M.S "Properties of HPC using Scrap steel for pavement application", Proceedings of National Get-together on Road Research and its Utilization, CRRI New Delhi, pages 80 - 82 (March 2012). 